\title{
A Review of the Literature on Employee Turnover
}

\author{
Aniss Ait Alla \\ Ph.D. Scholar \\ National School of Trade and Management \\ Science and technical management \\ Agadir, Morocco \\ Omar RAJÂA \\ Professor \\ National School of Trade and Management \\ Agadir, Morocco
}

\begin{abstract}
The issue of staff turnover has been the subject of growing interest in many organizations around the world. Indeed, it turns out that a significant part of these organizations were forced, at a certain stage of their development, to raise the issue. In this respect, organizations should be alerted to the rate of voluntary staff turnover because of the negative impacts it could have on the performance of their activities. The purpose of this article is to carry out a literature review on the various theoretical factors and trends that explain the phenomenon of voluntary turnover.
\end{abstract}

Keywords: Staff turnover- Voluntary turnover process - Voluntary turnover theories - Voluntary turnover costs.

\section{Introduction}

Voluntary turnover of staff is an alarming malfunction that businesses are constantly confronted with, so it is an important area of research from both a theoretical and a practical point of view. From a theoretical point of view, it is wise to understand the causes of voluntary turnover in a perspective aimed at anticipating and controlling the phenomenon. However, from a practical point of view, it is crucial to learn how to minimize the rate of voluntary turnover of qualified employees. This can be extremely helpful for an organization to reduce both the significant loss of human capital and the costs associated with the negative consequences of the employee's decision.

Anticipating and controlling staff turnover can be a difficult and embarrassing task for decision-makers within their organization due to a variety of explanatory factors. Many researchers have attempted to identify the different factors that contribute to staff turnover in the workplace. Indeed, this article will present and present the concept of staff turnover, the mobilized explanatory theories of the intention of voluntary turnover and the variables most used in the study of the factors influencing the intention of voluntary turnover.

We are able to present in this article the following elements:

- Definition and forms of turnover;

- Voluntary turnover costs

- The Voluntary Rollover Process;

- The intention of voluntary turnover.

- Explanatory theories of voluntary turnover

\section{Staff turnover:}

Staff turnover has been at the center of the topics covered in the organizational behavior literature. The interest of the subject has increased over the last decade, with more than a hundred studies published in the major management journals and subject areas of the same subject. (Hausknecht \& Trevor, 2017).

\section{Definition and forms of staff turnover}

The term turnover is often used to describe the departure of the employee from his organization Price (2001). It is generally defined as the number of employees who enter and those who leave an organization during a specific period. There are two types of staff turnover, voluntary or involuntary. With respect to the first form, an employee voluntarily decides to leave the organization for reasons that vary from employee to employee. 
Unintentional turnover is the result of an organization's decision to dismiss an employee for a specific reason (economic, technological, poor performance or serious misconduct ...) (Armstrong, 2012).

In other words, involuntary turnover is the result of redundancy actions, while voluntary turnover results from employees' decisions to leave the company voluntarily. The importance of this organizational phenomenon is such that studies on the subject abound. Most of these studies have focused on voluntary versus unintentional turnover (Wright, 1993). From this we conclude that voluntary turnover is a serious problem for both employees and organizations.

The voluntary turnover rate is indeed the total number of employees leaving the organization divided out of the total number of employees, often measured over a period of one year (Hausknecht \& Trevor, 2017).

Given the scale of the problem posed by voluntary turnover for the company, academics and practitioners have dedicated a great interest to it through their research and their organizational practices. Armstrong (2012) argues that turnover can be a disruptive phenomenon with costly repercussions for the organization. The assumption is corroborated by the fact that when an employee voluntarily leaves, his decision is likely to cause more negative consequences for the company than if an underperforming employee is dismissed.

Although the literature is full of many other definitions, Mobley's (1982) definition represents precisely the conceptual position of this thesis. Mobley states that voluntary turnover is "the cessation of membership in an organization by an individual who has received monetary compensation from the organization" (p.10).

\section{Voluntary turnover costs:}

Human resources managers and organizations in any economy have been constantly challenged by the challenges of staff turnover. The resignation of a competent and experienced employee is a very expensive act for the organization. Dess and Shaw, (2001).

The consequences of voluntary turnover vary between the financial costs that affect the financial position of the organization and the moral costs that can affect the well-being and productivity of employees:

- Psychological costs represented by overworking for employees remaining in the organization. This could lead to tensions that would in principle affect the social climate (Grissom, et al., 2012, Wang, et al., 2012).

- The productivity of the employee may be affected by the departure of his colleagues, especially if the employee was part of a good work network; the loss of an employee means the loss of a productive member who can destabilize the work environment (Wright \& Kim, 2004, Chen, 2008).

- Decrease in the quality of services offered to consumers. Tariq, et al., (2013).

- Recruitment costs and the risk of selecting a new undervalued or poorly integrated employee, as well as costs related to new employee training (Singh \& Longcar, 2010).

- The resigning employee leaves, with his assets expertise and achievements difficult to recover for the organization. This results in a growth in the learning curve of the new employee.

However, voluntary turnover should not be regarded as necessarily a dysfunctional phenomenon. In reality, the turnover of the non-productive employee, who may not have the necessary skills to fill the position, allows the company to renew and revitalize its teams on the one hand, and to allow the outgoing employee to find another job that best fits his skills and aspirations on the other hand.

\section{Process of voluntary turnover}

Mobley's model, (1978) proposes a series of steps forming the decision-making process to leave. (Yin-Fah et al., 2010, Kim, 2014). The process is triggered by an existing job evaluation phase (1). An employee evaluates his work based on several key factors. These allow him to determine what attitude he should have towards his position (2). The continuity of the employee in the position he currently holds depends on his job satisfaction. The existence of such satisfaction is the guarantee that the employee would continue in his position. On the other hand, if he feels dissatisfaction, the collaborator reacts by disengaging himself from his responsibilities. To do this, it becomes less efficient by adopting passive behaviors at work. At this level the employee is flattered by the idea of quitting his job, especially in case the feeling of dissatisfaction persists (3).

In addition, Michaels and Spector (1982) added another variable at this stage that is organizational involvement. Both researchers show that an employee who does not have a strong attachment to his or her organization begins to consider an assessment of the costs and benefits of trying to find a new job (4). Thus, when the employee infers from the evaluation made of high probabilities of finding another job, he looks for new opportunities outside his organization (5). Once this stage of the research is finished, it carries out the evaluation (6) and the comparison of the offered opportunities (7). At the end of the comparison conducted, the employee can have sufficient visibility that would allow him to judge whether these opportunities are not beneficial or if, conversely, they are advantageous. 
By this, the collaborator will develop an intention either to stay or leave his post, or even are organization (8). If he has developed an intention to leave, the last phase would be the start (9).

This model makes explicit that the intention to leave the organization can arise outside the decision-making process. In this case, the employee makes his decision in a sudden and very often impulsive manner. This leads him to give up immediately rather than taking the time to rationalize his decision to leave. Thus, failure at one stage of the process can bring an individual back to a previous stage.

\section{Intention of voluntary turnover}

Mobley's model emphasizes the interest that can be taken into account and the inclusion of the intention of departure as a crucial and immediate vector of effective departure, by resorting to the theory of reasoned action. introduced for the first time by Fishbein (1967) and developed by (Fishbein and Ajzen, 1975, Ajzen and Fishbein, 1980). This theory, which seeks to determine the relationship between the intention of an individual's behavior and the actual achievement of that behavior, is widely used by many researchers in several fields, Yousafzai et al., 2010; Beiginia et al. 2011; Abdelghani and Oladokun, 2012; Razak et al 2016.

The theory of reasoned action makes it possible to apprehend the voluntary behavior of an individual and states that the best way to predict voluntary behavior is intention, which is the cognitive representation of a person's disposition to perform a behavior. given. It is considered the immediate antecedent of behavioral realization. Fishbein (1967). Indeed, Behavioral intent is based on attitudes and subjective norms to this behavior.

Behavioral attitude is the positive or negative perception of the individual as to the performance of the desired behavior. It is determined by an assessment of one's beliefs about the consequences and opportunities of attaining behavior.

The subjective norm refers to the perception of an individual that most reference people think should or should not perform the behavior. According to this theory, the more a person perceives that other people important to him think that he should or should not perform a behavior, the more he intends to do it or not to do it. Nevertheless, the tendency of individuals to perform a behavior does not lead to the realization or concretization of their intention in reality. This prompts to question the need to introduce the degree of behavioral control.

Indeed, Ajzen has extended the theory of reasoned action to the theory of planned action by including the perceived behavioral control that defines it as the presence or absence of factors that may facilitate or hinder the achievement of behavior.

In other words, beliefs about behavioral control refer to an individual's perceptions of his ability to perform a given behavior as an additional determinant of behavioral intent. Thus, in an organizational context, the birth of the intention of voluntary turnover occurs as soon as a collaborator seriously and deliberately considers the final decision to leave work in his organization (Omar et al., 2012, Jung and Yoon.2012) Indeed, researchers have dedicated a greater interest to the intention of voluntary turnover. This attention on the part of academicians can be explained by the fact that the role of this intention as an immediate determinant of voluntary turnover is confirmed by several works.

As a result, according to the Planned Action Theory, the intent of the roll becomes effective when individuals perceive that they control the decision to leave. In the same logic, there are a number of reasons why individuals might perceive less control over this decision. (Griffeth and Peter, 2004) describe that:

- Family or financial constraints may restrict the decision to leave;

- Individuals are investing more and more in an organization over time, making it more difficult to leave (Becker, 1960);

- Perceptions of availability and quality of alternatives may affect perceived control.

\section{Explained explanatory theories of voluntary turnover:}

This section explains the mobilized theories that explain the phenomenon of voluntary turnover in this research. We will present in the following theories:

The theory of organizational equilibrium;

The theory of social exchange

The unfolding theory;

Job embeddedness theory. 


\subsection{Theory of organizational Equilibrium:}

The theory of organizational equilibrium proposed by Marsh and Simon in 1958, considered as the first formal theory of turnover (Holtom et al., 2008 cited in Ngo-Henha, 2017), emphasizes the need to create a balance between contributions employees and the incentives offered by the organization. To this end, each organization must ensure that its employees benefit from equitable incentives that would stimulate the continuity of their contributions. This balance is influenced by two major considerations: (1) the perceived desire to leave the position, (2) the perceived ease of movement for the collaborator.

The perceived desire to leave the post is explained by the satisfaction / dissatisfaction at work felt by the collaborator on the one hand, and the possibility / impossibility of an intra-organizational transfer on the other hand.

When the employee perceives that his satisfaction with the position held is guaranteed, his tendency to leave his position is therefore less desirable. However, his dissatisfaction may push him to seek intra-organizational transfer. The existence of this possibility, which depends mainly on the size of the organization, would substantially reduce the chances of leaving the job. Indeed, the larger the organization, the more the possibilities of transfer exist and the less the staff tends to leave. The second factor is the ease of perceived employee movement or the number of alternatives available. An employee in this case would easily leave his current organization, as the number of external offers at his disposal is reassuring and advantageous.

The theory of organizational equilibrium suggests, in fact, that the probability of voluntary leaving is a function of the desire to leave and the perceived ease of departure. If the employee has no desire to leave his position, then the perceived ease of departure is not important to him. On the other hand, a collaborator who is very dissatisfied within the organization and who, therefore, expresses his wish to leave it, would not hesitate to seize the first external alternative, provided that it is advantageous.

\subsection{Theory of social exchange}

The theory of social exchange has been widely adopted in recent years by researchers in management sciences (Brimhall, Lizano \& Barak, 2014, Singh and Selvarajan, 2013, Ertürk and Vurgun, 2015, George, 2015, Cheng \& Waldenberger, 2013, Singh et al, 2013, Thurasamy et al., 2011, Taştan, 2014).

Blau (1964), cited in Paillé et al. (2015), states that social exchange is based on "favors that create diffuse future obligations, not precisely specified, and whose nature of the counterpart can not be negotiated. but must be left to the discretion of its author.

Indeed, Blau explains social exchange as a process of exchange between parties who take responsibility for each other vis-à-vis others in a long-term relationship of strong interdependence.

In this context, this relationship is guided by the norm of reciprocity integrating two essential notions namely: the respect of obligations and the feeling of accountability. Caroline (2008).

Gouldner (1960) emphasizes that "people must help those who have helped them and people must not hurt those who have helped them". The reciprocity standard requires the party who has benefited from favorable treatment to provide similar treatment in return. In other words, when a party provides a benefit, the receiving party is obliged to respond in kind. The opposite would then be so true; when negative treatment is shown, the natural and predictable response would be similar treatment or behavior.

Reciprocal relations between the two parties have an influence on employee behavior (Wittmer et al, 2010). Stronger relationships will have a direct impact on the attitudes and behaviors of members. Indeed, employees who are strongly identified with their organizations are likely to work intensively to achieve organizational goals, which would increase their performance at work. These same employees show greater loyalty and therefore tend to continue in their organizations.

This reciprocal relationship results in a lower voluntary turnover rate and generally lower withdrawal behaviors (eg, delay, absence). In this sense, (Avanzi et al., 2014) confirmed that the failure of the social exchange relationship is the cause of high rates of voluntary turnover. Finally, employees who are more strongly identified and committed to their organization show greater satisfaction with their work compared to their weakly identified colleagues.

It is maintained by the theory of exchange that all human relations emanate from the use of the subjective cost-benefit ratio through which the parties maintaining these relationships aspire to maximize their respective interests and reduce losses (Thibaut and Kelley, 1978). Indeed, it happens that employees are likely to preserve and continue the relationship with their employer when they feel that it is valuable to them, and dissolve it when the costs exceed the rewards they receive. 
In other words, a report whose profits exceed the costs would be more satisfactory and more sustainable. On the other hand, if the report offers more costs than benefits, it would be less satisfactory and less durable. (Tse et al, 2013).

However, the above rule is not always respected: there are some people who tend to maintain unsatisfactory relationships or put an end to happy relationships. What determines whether an individual will maintain or leave a relationship is the set of alternative relationships available (Kelley and Thibaut, 1978).

In this context, if several alternatives are presented to him, then this individual will be less dependent on his relations. This notion of dependence is formalized as the difference between the benefit of the relationship and the "comparison level of alternatives". (Kelley and Thibaut, 1978).

When he decides to finish a report, an employee considers his alternatives while taking into account other points, such as the "brakes" to leave this relationship. It also takes into account the degree of investment put into this relationship.

\subsection{The unfolding theory}

The unfolding theory put in place by Lee and Mitchell in 1991 states that an employee who, at a given point in time, decides to leave a given organization, would follow one of the five cognitive pathways. A cognitive way refers to the way in which this employee evaluates his or her work environment to choose possible options and find appropriate answers.

The first three routes are triggered by a kind of shock event. Shock is defined as "a very distinctive event that pushes the employee toward deliberate judgments about his work and, which may lead to it, to voluntarily give up his job" (Lee \& Mitchell, 1994: 60).

The first way: according to this theory, the first path begins with a personal shock, positive and expected, which is an automatic behavioral response in which the employee is ready to leave his organization because he has for example the possibility to move in a new city (Holtem et al., 2005).

The second way: contrary to the previous trajectory, the employee in this way does not have preprogrammed answers. For this purpose, all that is required is an organizational event in which the employee perceives a negative shock factor such as maltreatment on the part of management, internal inequity, etc. for him to immediately question his involvement and loyalty to the organization for which he works. Lee and Mitchell, (1991).

The third way: here the employee starts to compare his current job with another job because of a shock. What makes this path different from the second way is the shock element that is generally positive. Thus, a promising job offer would encourage the employee to leave even though his current position is satisfactory. We therefore deduce that the job offer creates the element that attracts the employee.

The fourth way: a continuous feeling of dissatisfaction is at the root of this path that can not be justified by a shock. It consists of two paths that separate because of the way the employee responds to this dissatisfaction. Both paths can be explained as follows:

Way 4 A: leaving a job in an unthinking way: the employee is impulsive due to dissatisfaction with his work, which causes him to resign even in the absence of a prior plan or alternative.

Path 4 B: Ensure alternative availability and then resign: Unlike 4A, the employee in this experiment is patient despite his job dissatisfaction. Conscious of the lack of alternatives, he prefers to tolerate the status quo and the resignation of his post could only take place if another job was available.

\subsection{Job embeddedness theory}

The theory of job embeddedness was developed by (Mitchell et al., 2001) to explain how various factors such as family, co-workers, or even the work itself may condition an individual's decision in the report. that he maintains vis-àvis his work. In other words, this theory seeks to understand how these factors affect the employee in his decision to stay or give up his position. It presents three situational dimensions related to the relationship of the employee with the organization and its relationship with the community, these three factors are brought together to explain the reason why an employee is attached or not to his work:

- Links: links can be divided into two categories: organizational links and community links. Organizational links consist of all the connections (formal or informal) that an employee has developed during his or her work time with colleagues, supervisors or the number of teams or working committees to which an employee belongs. According to this theory, the employee who has been able to acquire a strong relational sense within his organization, would consequently develop an attachment to his work. The second category of links is community. These are links that we maintain within the society we belong to, that we have with those who live in our geographic region (friends, neighbors, family). In short, an employee who can not develop strong relationships with his organizational and community environment, can only be less attached to it. 
- Adjustment: is described as the "perception of compatibility or comfort level" of an employee with the organization and its environment. According to this theory, it is the degree of correlation between the employee's skills, career goals, and personal values with the organization that determines his degree of attachment to his work and organization.

- Sacrifice: at the organizational level, we are dealing with sacrifice, when an employee abandons a professional situation favorable to know colleagues with whom he gets along well, the stability of employment or, in general, the great harmony that the we have with the organization, and eventually leave his job and his social level. Community sacrifice therefore refers to the ability to abandon one's social network.

In general, these factors create a force that influences the employee's decision to remain in his job.

\section{Conclusion:}

To conclude, we can say that voluntary turnover is the action initiated by the employee to voluntarily leave the company that employs him. This phenomenon has negative repercussions on the psychology and productivity of employees as well as on the overall performance of the company.

In addition, the theory of planned action, the intention of the rotation becomes effective when individuals perceive that they control the decision to leave. Indeed, researchers have dedicated a greater interest to the intention of voluntary turnover. This attention on the part of academicians can be explained by the fact that the role of this intention as an immediate determinant of voluntary turnover is confirmed by several works.

During this work, we were able to explain the mobilized explanatory theories of intention of voluntary turnover as part of this research work. Namely: the theory of organizational equilibrium, the theory of social exchange, the unfolding theory and Job embeddedness theory.

\section{References:}

Abdelghani, E \& N.O. Oladokun. (2012). Malaysian Consumers' Preferences for Islamic Banking Attributes. International Journal of Social Economics. 39 (11): 859 - 874.

Ajzen , I., \& Fishbein, M. (1980). Under rstanding attitudes and predicting social behavior . Englewood Cliffs, NJ : Prentice-Hall,89-93p

Armstrong, M. (2012). Armstrongs Handbook of Human Resource Management Practice. (12e éd.) London : Kogan, $43-47 \mathrm{p}$

Avanzi, L. Fraccaroli, F., Sarchielli, G., Ullrich, J. and van Dick, R. 2014. Staying or leaving A combined social identity and social exchange approach to predicting employee turnover intentions, Int. J. Product. Perform. Manag, 63, (3),272-289.

Becker, H. S. (1960). Notes on the concept of commitment. American Journal of Sociology, 66, 32.42.

Beiginia, A. R., Besheli, A. S., Soluklu, M. E., \& Ahmadi, M. (2011). Assessing the mobile banking adoption based on the decomposed theory of planned behaviour. European Journal of Economics, Finance \& Administrative Sciences, 28(1), 7-15.

Brimhall, K. C., Lizano, E. L., \& Barak, M. E. M. (2014). The mediating role of inclusion : A Longitudinal study of the effects of leader-member exchange and diversity climate on job satisfaction and intention to leave among childwelfare workers. Children and Youth Services Review, 40(1), 79-88.

Caroline, R. le soutien social au travail : conceptualisation, mesure et influence sur l'épuisement professionnel et l'implication organisationnelle : l'étude d'un cas hospitalier. Sciences de l'Homme et Société. Université Rennes 1, 2008.

Chen, L. (2008). Job satisfaction among information system (IS) personnel. Computers in Human Behavior, 24(1),105118.

Cheng, Y. and Waldenberger, F., 2013. Does Training Affect Individuals' Turnover Intention? Evidence from China. Journal of Chinese Human Resources Management, 4(1), 16-38.

Dess, G.D. and Shaw, J.D. (2001). Voluntary turnover, social capital, and organizational performance. Academy of Management Review, 26 (3), 446-56.

Ertürk, A., \& Vurgun, L. (2015). Retention of IT professionals: Examining the influence of empowerment, social exchange, and trust. Journal of Business Research, 68(1), 34-46.

Fishbe in, M. (1967). Attitude and the prediction of behavior. In M. Fishbein (Ed.), Readings in attitude theory and measurement. New York: Wiley, 477-492p.

Fishbe in, M., \& Ajzen, I. (1975). Belief, attitude, intention and behavior:An introduction to theor y and research. Reading, MA: Addison-Wesley,156-161p. 
George, C. (2015) Retaining professional workers: what makes them stay? Employee Relations. [Online] Emerald, 37(1), 102.

Gouldner, A. (1960). The norm of reciprocity: A preliminary statement. American Sociological Review, 25(2), 161178. doi:10.2307/2092623

Griffeth, R. W., Hom, P. W., \& Gaertner, S. (2000). A meta-analysis of antecedents and correlates of employee turnover: Update, moderator tests, and research implications for the next millennium. Journal of Management, 26(3), 463-488.

Grissom, J. A., Nicholson-Crotty, J. \& Keiser, L. (2012). Does my boss's gender matter? Explaining job satisfaction and employee turnover in the public sector. Journal of Public Administration Research \& Theory, 22 (4), 649673.

Hausknecht, J. P. (2017). Collective Turnover. Annual Review of Organizational Psychology and Organizational Behavior, 4(1), 527-544. https://doi.org/10.1146/annurev-orgpsych-032516-113139.

Holtom, B. C., Mitchell, T. R., Lee, T. W., \& Inderrieden, E. J. (2005). Shocks as causes of turnover: What they are and how organizations can manage them. Human Resource Management, 44(1), 337-352.

Jung, H. S., \& Yoon, H. H. (2013). The effects of organizational service orientation on person-organization fit and turnover intent. The Service Industries Journal, 33(1), 7-29. doi: 10.1080/02642069.2011.596932

Kelley, H. H. \& Thibaut, J. W. (1978). Interpersonal relations : A theory of interdependence. (2e éd.) New York : Wiley, 76-78p.

Kim, A., \& Mor-Barak, M. E. (2014). The mediating roles of leader-member exchanges and perceived organizational support in the role stress-turnover intention relationship among child welfare workers: A longitudinal analysis. Children and Youth Services Review, 52(1), 135-143.

Lee, T. W., \& Mitchell, T. R. (1991). The unfolding effects of organizational commitment and anticipated job satisfaction on voluntary employee turnover. Motivation and Emotion, 15(1), 99-121.

Lee, T. W., \& Mitchell, T. R. (1994). An alternative approach: The unfolding model of voluntary employee turnover. The Academy of Management Review, 19(1), 51-89.

Michaels, C. E., \& Spector, P. E. (1982). Causes of employee turnover : A test of the Mobley, Griffeth, Hand, and Meglino model. Journal of Applied Psychology, 67(1), 53-59.

Mitchell, T. R., Holtom, B. C., Lee, T. W., Sablynski, C. J., \& Erez, M. (2001). Why people stay: Using job embeddedness to predict voluntary turnover.Academy of Management Journal, 44(1), 1102-1121. doi: $10.2307 / 3069391$.

Mobley, W. (1982). Employee Turnover : Causes, Consequences, and Control. Addison-Wesley : Reading, MA, 10p.

Mobley, W.H., Horner, S.O., \& Hollingsworth, A.T. (1978). An evaluation of precursors of hospital employee turnover. Journal of Applied Psychology, 63(4), 408-414.

Ngo-Henha, P. E. (2017). A Review of Existing Turnover Intention Theories. International Journal of Economics and Management Engineering, 11(11), 2751-2758.

Omar, F., Halim, F.W., Zainah, A. Z., Farhadi, R., Nasir, R., Khairudin, R. (2012). Stress and job satisfaction as antecedents of workplace deviant behavior. World Applied Science Journal. 12(Special Issue), 46-51.

Paillé, P., N. Raineri and P. J. Valeau, 2015. Professional employee retention: Examining the relationships between organizational citizenship behavior and turnover cognitions. The Journal of Applied Business Research, 31(4), $46-56$.

Price, J. L. (2001). Reflections on the determinants of voluntary turnover. International Journal of Manpower, 22(7), 600-624. https://doi.org/10.1108/EUM0000000006233.

Razak,N.A., Faizuniah P., Md Lazim M. Z., Noor A. M. Y., Nini H. A.(2016.)Theories of Knowledge Sharing Behavior in Business Strategy,Procedia Economics and Finance, 37(1)45-553, https://doi.org/10.1016/S22125671(16)30163-0.

Singh, B.,\&Selvarajan, T. T. (2013). Is it spillover or compensation ? Effects of community and organizational diversity climates on race differentiated employee intent to stay. Journal of Business Ethics, 115(2), 259-269.

Singh, P. \& Loncar, N. (2010). Pay satisfaction, job satisfaction and turnover intention. Industrial Relations, 65(3),470490.

Singh, R., Fouad, N. A., Fitzpatrick, M. E., Liu, J. P., Cappaert, K. J. and Figuereido, C., 2013. Stemming the Tide: Predicting Women Engineers' Intentionsto Leave. Journal of Vocational, 83(3), 281-294.

Tariq, M., Ramzan, M. \& Raiz, A. (2013). The impact of employee turnover on the efficiency of the organization. Interdisciplinary. Journal of Contemporary Research in Business, 4 (9), 700-711.

Tastan, S.B. (2017). Toxic workplace environment: in Search for the toxic behaviours in organizations with a research in healthcare sector. Postmodern Openings, 8(1), 83 109, http://dx.doi.org/10.18662/po/2017.0801.07Â 
Thurasamy, R., Lo, M. C., Amri, A. Y., \& Noor, N. (2011). An analysis of career advancement among engineers in manufacturing organizations. International Journal of Commerce and Management, 21, (2), 143-157.

Tse, H.H.M., Huang, X., Lam, W. (2013). Why does transformational leadership matter for employee turnover ? A multi-foci social exchange perspective. The Leadership Quarterly Journal, 24 (1), 763-776.

Wang, Y., Yang, C. \& Wang, K. (2012). Comparing public and private employees job satisfaction and turnover. Public Personnel Management, 41 (3), 557-573.

Wittmer, I., Bader, H.P., Scheidegger, R., Singer, H., Lu“ ck, A., Hanke, I., Carlsson, C., Stamm, C., 2010. Significance of urban and agricultural land use for biocide and pesticide dynamics in surface waters. Water Research, 44(9), $2850-2862$.

Wright, B. E. \& Kim, S. (2004). Participation's influence on job satisfaction. Review of Public Personnel Administration, 24(1), 18-40.

Wright, T. A., \& Bonett, D. G. (1993). Role of Employee Coping and Performance in Voluntary Employee Withdrawal: A Research Refinement and Elaboration. Journal of Management, 19(1), 147-161. https://doi.org/10.1177/014920639301900110.

Yin-Fah, B. C., Foon, Y. S., Chee-Leong, L., \& Osman, S. (2010). An exploratory study on turnover intention among private sector employees. International Journal of Business and Management, 5(1), 57-64.

Yousafzai, S., Foxall, G.R. (2010). Explaining internet banking behavior: Theory of reasoned action, theory of planned behavior, or technology accept 